\title{
METHODS OF CALCULATING THE PROBABLE \\ NUMBER OF FIRE TO BE ELIMINATED \\ BY THE GAS PROTECTION SERVICE
}

\author{
МЕТОДИКА РОЗРАХУНКУ ІМОВІРНОЇ \\ КІЛЬКОСТІ ПОЖЕЖ, ЯКІ БУДУТЬ \\ ЛІКВІДОВУВАТИСЬ ГАЗОДИМОЗАХИСНИКАМИ
}

\section{Oleksandr Cherkashyn ${ }^{1}$ \\ Sergii Shcherbak ${ }^{2}$}

DOI: https://doi.org/10.30525/978-9934-26-077-3-24

Abstract. The main types of operational actions of fire and rescue units during firefighting and emergency response are presented. An analysis of fires that have occurred during the last five years, which have been extinguished by units of the State Emergency Service of Ukraine with the participation of units of the gas and smoke protection service. After analyzing the statistics of the number of fires and emergencies in the city (district) over the years, a mathematical model of the dynamics of the number of fires and other emergencies. The forecast of the expected number of their occurrence is determined and the volume of work of the gas and smoke protection service for the next year is estimated, as well as the sufficiency of forces and means is determined. The most effective way to identify the main trend in the number of emergencies is analytical alignment using a mathematical expression that most accurately describes the nature of the empirical distribution of their number over the analyzed period and with which you can make predictions. To do this, the necessary mathematical distribution law is selected in the scientific search. To determine the speed and intensity of the number of fires and other emergencies over time, the following indicators were used: absolute growth, growth rate. The calculation of these indicators is based

\footnotetext{
${ }^{1} \mathrm{PhD}$ in Pedagogical Sciences,

Senior Lecturer at the Department of Fire and Rescue Training,

National University of Civil Defence of Ukraine, Ukraine

${ }^{2} \mathrm{PhD}$ in Engineering Sciences,

Senior Lecturer at the Department of Fire and Rescue Training,

National University of Civil Defence of Ukraine, Ukraine

(C) Oleksandr Cherkashyn, Sergii Shcherbak
} 
on comparing the levels of a number of dynamics. Under the level of a series of dynamics is taken each individual numerical value of the indicator, which characterizes the magnitude of the phenomenon, its size and location in chronological order. Based on the described indicators, a method of calculating the probable number of fires in the current year, which will be eliminated by the gas and smoke protection service, is proposed. An example of calculation is given: its main components are described, which should be taken into account during the calculation. The process of change and development of the occurrence and spread of fires by constructing time or time series is studied. Recommendations for building a mathematical model of the dynamics of the number of fires and other emergencies are given, the forecast of the expected number of their occurrence is determined, the volume of work of fire and rescue units for the next year is estimated.

\section{1. Вступ}

Згідно із статистичними даними, у порівнянні з аналогічним періодом минулого року, кількість пожеж збільшилась на 23,1 \%. Кількість загиблих внаслідок пожеж зменшилась на 1,2\%, кількість травмованих на пожежах збільшилась на 0,9\%. Кількість дітей і підлітків до 18 років, які загинули внаслідок пожеж, збільшилась на 14,9\%, кількість дітей і підлітків до 18 років, травмованих на пожежах збільшилась на $2,7 \%$.

На об'єктах соціально-культурного, громадського та адміністративного призначення кількість загиблих збільшилась у 2,9 рази.

Матеріальні втрати від пожеж збільшились на 32,2\% (прямі збитки збільшились на 3,9\%, побічні - на 42,4\%), кількість знищених і пошкоджених будинків (споруд) збільшилась на 2,9\%, кількість знищених і пошкоджених транспортних засобів (техніки) - на 2,9\%, кількість загиблих свійських тварин - у 2,2 рази, кількість знищеного хліба на корені (га) та у валках - на 44,5\%, кількість знищеного зерна зменшилась на 40,0\%, кількість загиблих свійських птахів - на 61,5\%, кількість знищених кормів - на 40,0\%.

Упродовж 2020 року на місці пожежі виявлено 1667 загиблих людей, з них 49 дітей.

Унаслідок пожеж загинуло 1660 людей, в тому числі 54 дитини, 1372 людини отримало травми, у тому числі 113 дітей. 
Матеріальні втрати від пожеж склали 10 млрд 75 млн 259 тис. грн (3 них прямі збитки становлять 2 млрд 82 млн 664 тис. грн, а побічні 7 млрд 992 млн 595 тис. грн).

Щодня в Україні, в середньому, виникало 275 пожеж, матеріальні втрати від яких складали 30 млн 165 тис. грн. Кожного дня внаслідок пожеж гинуло 5 і отримувало травми 4 людини, вогнем знищувалось або пошкоджувалось 72 будівлі (споруди) та 13 одиниць техніки. Прямі збитки від однієї пожежі становили 22,7 тис. грн. [1].

Дослідження проблеми протипожежного захисту будинків за їх поверховістю вказують, що щорічно близько $75 \%$ пожеж виникають у малоповерхових будинках (заввишки $\mathrm{H} \leq 9$ м, як правило, до 3-х поверхів включно); ще майже $5 \%$ пожеж припадає на багатоповер-

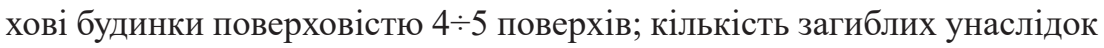
пожеж, що виникали в $1 \div 3$ - поверхових будівлях щороку становить

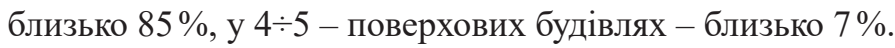

Незважаючи на зменшення кількості пожеж на 5,4\% у 2020 році порівняно з 2019 роком, упродовж останніх п'яти років їх кількість залишається значною та становить у середньому близько 77 тисяч пожеж на рік. Також спостерігається стала тенденція до зростання збитків від пожеж. Зареєстровано збільшення загиблих унаслідок пожеж у будівлях і спорудах житлового призначення $(+8,9 \%)$, причому, у житлових будинках $(+7,8 \%)$. Аналогічний стан склався і 3 травмуванням людей у пожежах.

Актуальність напрямку дослідження говорить про недостатній рівень дослідження динаміки виникнення пожеж та надзвичайних ситуацій в містах (районах) по роках; не визначається прогноз очікуваного числа їх виникнення та обсяг роботи ланками газодимозахисної служби на найближчий рік, а також достатність сил і засобів, які слід залучати.

Метою роботи є розробка методики розрахунку імовірної кількості пожеж, які будуть ліквідовуватись ланками газодимозахисної служби.

Досягнення поставленої мети потребує вирішення наступних завдань:

1. Теоретично обгрунтувати методику розрахунку імовірної кількості пожеж, які будуть ліквідовуватись ланками газодимозахисної служби;

2. Провести розрахунок імовірної кількості пожеж, які будуть ліквідовуватись ланками газодимозахисної служби у 2021 році. 


\section{2. Аналіз літературних даних та постановка проблеми}

Для гасіння пожеж та ліквідації надзвичайних ситуацій ведуться різні оперативні дії в умовах складної обстановки, вдень і вночі, при високих і низьких температурах, в задимленому і отруєному середовищі, на висотах і в підвалах, в умовах вибухів, обвалів, землетрусів та інших стихійних лих [2].

Оперативні дії класифікуються за характером і призначенням. Принципова схема класифікації оперативних дій на прикладі одного підрозділу наведена на рис. 1.
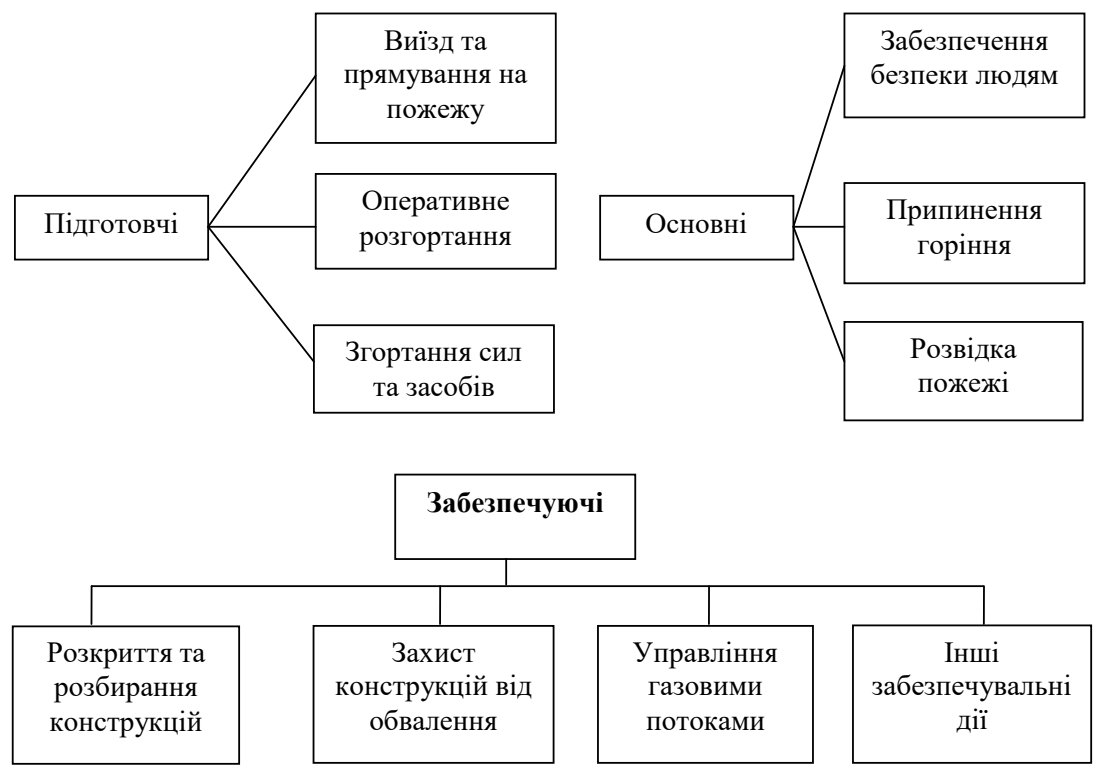

3 рисунка видно, що подача вогнегасних речовин $€$ не тільки основним, але і загальним видом оперативних дій підрозділів. У той же час безпека людей і тварин (порятунок, евакуація або захист їх різними засобами), хоча і належить до основного виду оперативних дій підрозділів, але $є$ окремим, оскільки виконується не на всіх пожежах [3].

Відмінною особливістю загальних оперативних дій підрозділу є те, що вони виконуються в суворій послідовності, а тому відносяться до послідовних процесів. 
Окремі оперативні дії підрозділу виконуються, як правило, паралельно з деякими загальними, такими, як оперативне розгортання та подача вогнегасних речовин.

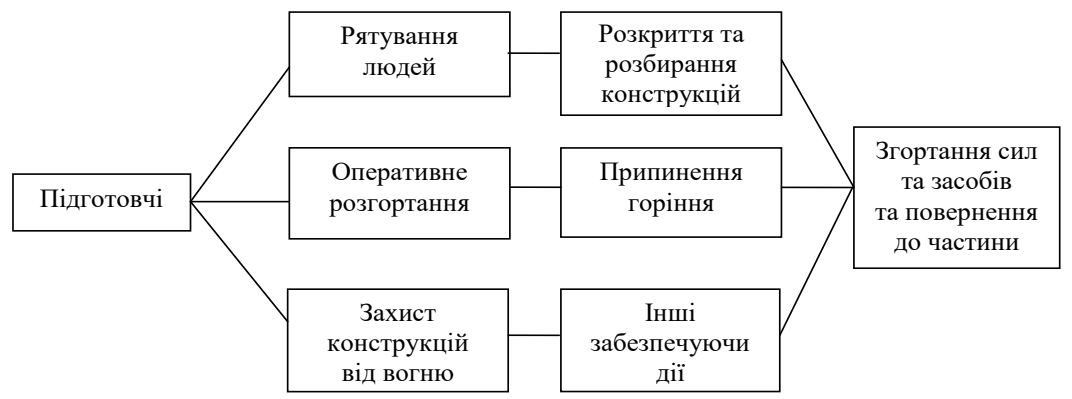

\section{Рис. 2. Послідовність виконання дій одним пожежно- рятувальним підрозділом (послідовно-паралельний процес)}

Оперативні дії підрозділів завжди обмежені в просторі і часі. Вони здійснюються на порівняно невеликій території і більш-менш швидкоплинно.

Тривалість оперативних дій підрозділів визначається часом, необхідним для виконання оперативного завдання на пожежі, і залежить від умов оперативної обстановки, кількості, оперативності та боєздатності підрозділів. Вона починається з моменту виїзду підрозділів на пожежу і закінчується моментом постановки їх в оперативний розрахунок після виконання поставлених завдань на пожежі [4].

Зміст і особливості оперативних дій підрозділів визначаються оперативно-тактичною обстановкою на пожежі і в цілому мають загальний характер. Тим не менш, залежно від кількості підрозділів, які прибули на пожежу, їх оперативні дії характеризуються деякими кількісними показниками, що різняться між собою. Практично, а особливо в початковій стадії гасіння пожежі, більшість і навіть всі види оперативних дій можуть виконуватися одночасно, в комплексі.

Активність опертивних дій поляге у своєчсному використанні вигідних умов обстановки пожежі і своїх можливостей («зупинити» вогонь, поки він не перекинувся на сусідні будівлі, не поширився на інші приміщення), у ініціативі кожного пожежника і командира (іні- 
ціативні рішення і дії на пожежі повинні відповідати загальному задуму КГП, начальника оперативної дільниці).

Активно й успішно вести оперативні дії можуть підрозділи, добре навчені та підготовлені, психологічно стійкі які знають конструктивні особливості будівель і споруд, протипожежне водопостачання на ділянці пожежі, оснащені засобами зв'язку та протидимного захисту [5; 6; 7]. Важлива складова частина боротьби за підвищення активності оперативних дій - навчання особового складу чіткому виконанню оперативного розгортання, швидкому виходу ствольщиків на позиції безпосереднього виконання завдань, використання для досягнення поверхів і якнайшвидшого введення стволів в осередок пожежі ручних і автодрабин, підйомників, поєднання роботи ствольщиків зі своєчасним розкриттям і розбиранням конструкцій $[8 ; 9 ; 10 ; 11]$.

Згідно 3 аналізом ліквідованих пожеж підрозділами ДСНС у 2016-2020 pp. за участю ланок ГДЗС, видно, що час роботи однієї ланки ГДЗС в середньому становить 22 хв. або $62 \%$, а двома та більше ланками ГДЗС 36 хв або 38 \% (табл. 1) [1; 12; 13].

Таблиця 1

Аналіз ліквідованих пожеж підрозділами ДСНС України за 5 років за участю ланок ГДЗС

\begin{tabular}{|c|c|c|c|c|c|c|}
\hline \multirow[b]{2}{*}{ Рік } & \multirow[b]{2}{*}{$\begin{array}{c}\text { Кількісь } \\
\text { ліквідованих } \\
\text { пожеж, } \\
\text { всього }\end{array}$} & \multicolumn{5}{|c|}{ Ліквідовано пожеж за участю ланок ГДЗС } \\
\hline & & всього & $\begin{array}{c}\text { однією } \\
\text { ланкою }\end{array}$ & $\begin{array}{c}\text { час } \\
\text { роботи } \\
\text { однією } \\
\text { ланкою, } \\
\text { хв. } \\
\end{array}$ & $\begin{array}{c}\text { двома та } \\
\text { більше } \\
\text { ланками. }\end{array}$ & $\begin{array}{c}\text { час роботи } \\
\text { двома } \\
\text { та більше } \\
\text { ланками, } \\
\text { хв. } \\
\end{array}$ \\
\hline 2016 & 65635 & 9961 & 6479 & 145280 & 3482 & 145237 \\
\hline 2017 & 78174 & 10803 & 6797 & 149731 & 4006 & 147561 \\
\hline 2018 & 78174 & 10803 & 6797 & 149731 & 4006 & 147561 \\
\hline 2019 & 82986 & 11523 & 8102 & 195478 & 3421 & 143015 \\
\hline 2020 & 78357 & 10751 & 7837 & 177190 & 2916 & 118516 \\
\hline
\end{tabular}

3. Теоретичне обгрунтування методики розрахунку

Одне $з$ основних завдань статистики полягає в дослідженні процесу зміни і розвитку досліджуваних явищ за допомогою побудови динамічних або часових рядів. 
Проаналізувавши статистичні дані кількості пожеж та надзвичайних ситуацій в місті (районі) по роках, можна побудувати математичну модель динаміки числа пожеж та інших НС, визначити прогноз очікуваного числа їх виникнення, а, отже, й оцінити обсяг роботи гарнізону на найближчий рік, визначити достатність сил і засобів. Найбільш ефективним способом виявлення основної тенденції розвитку числа $\mathrm{HC} €$ аналітичне вирівнювання за допомогою математичного виразу, що найбільш точно описує характер емпіричного розподілу їх кількості за аналізований період і за допомогою якого можна виконувати прогнозування. Для цього необхідно підібрати необхідний математичний закон розподілу.

Для визначення швидкості та інтенсивності розвитку кількості пожеж та інших НС за певний час розраховуються наступні показники: абсолютний приріст, темп зростання, темп приросту.

Розрахунок цих показників грунтується на порівнянні між собою рівнів ряду динаміки.

Під рівнем ряду динаміки розуміється кожне окреме чисельне значення показника, який характеризує величину явища, його розмір i розташування в хронологічній послідовності.

Якщо кожний рівень ряду порівнюється з попереднім, то визначені показники називають ланцюговими; якщо усі рівні порівнюються 3 рівнем, який виступає як постійна база порівняння - базисними.

Абсолютний приріст (зменшення) - це різниця рівнів динамічного ряду:

- ланцюгові

- базисні

$$
\Pi_{i}=Y_{i}-Y_{i-1}
$$

$$
\Pi_{i}=Y_{i}-Y_{0}
$$

де $\Pi_{i}-$ абсолютний приріст;

$Y_{i}$ - порівнюваний рівень;

$Y_{0}, Y_{i-1}-$ базисний рівень.

Абсолютний приріст за одиницю часу вимірює абсолютну швидкість зростання. Однак більш повну характеристику процесу росту можна отримати тільки тоді, коли абсолютні величини доповнюються величинами відносними, якими є темпи зростання і темпи приросту. Вони характеризують відносну швидкість зміни рівня, тобто інтенсивність процесу зростання. 
Темп зростання розраховується як відношення рівнів ряду, визначається коефіцієнтом або відсотком:

- ланцюгові

- базисні

$$
k_{i}=\frac{Y_{i}}{Y_{i-1}},
$$

$$
k_{i}=\frac{Y_{i}}{Y_{0}} .
$$

Темп приросту характеризує відносну величину приросту і показує, на скільки відсотків рівень $Y_{i}$ більший (менший) за базисний рівень:

$$
T_{i}=\frac{\Pi_{i}}{Y_{i-1}} 100 \%=\left(k_{i}-1\right) 100 \%
$$

Як і абсолютний приріст, темп приросту може бути позитивним та негативним, що свідчить про збільшення або зменшення рівня.

Якщо рівень явища на етапі його розвитку, що вивчається, постійно зростає або постійно знижується, то основна тенденція є явною і чіткою.

Для кількісної характеристики загальних результатів дії чітко вираженої основної тенденції, можна використовувати абсолютний приріст, темп зростання і приросту за увесь етап розвитку явища.

Якщо ланцюгові показники динаміки, залишаючись увесь час позитивними чи негативними, різко коливаються від року до року, або постійно змінюють свій знак, розрахунок їх величини за раніше наведеними формулами може дати невірну уяву про середню швидкість зміни рівня, відповідної загальної тенденції. Тому, в цих випадках, слід порівнювати не річні, а більш типові і тривалі середньорічні рівні. Для цього звичайно проводять збільшення інтервалів, до яких відносять рівні інтервального ряду динаміки. Збільшення інтервалів складається в переході від добових до тижневих, або декадних, від декадних до місячних, від місячних до квартальних чи річних, від річних до багаторічних. Розрахунок показників аналізу динаміки в цих випадках слід проводити модифікованими формулами.

Найбільш ефективним засобом виявлення основної тенденції розвитку є аналітичне вирівнювання. При цьому рівні ряду динаміки виявляються у вигляді функції часу $y=f(t)$. Вибір функції здійсню- 
ється на основі аналізу характеру закономірностей динаміки кількості надзвичайних ситуацій та пожеж.

Якщо характер динаміки підтверджує припущення про те, що рівень явища зростає з більш чи менш постійною швидкістю, тобто 3 відносно постійними абсолютними одиницями приросту, то математичним виразом такої тенденції буде пряма лінія. Аналітичне рівняння прямої має вигляд:

де $\hat{Y}_{t}$ - визначені рівні;

$$
\hat{Y}_{t}=a_{0}+a_{1} t
$$

$t$ - час, тобто порядковий номер інтервалу чи моменту часу;

$a_{0}, a_{1}-$ параметри прямої.

Розрахунок параметрів створюється за допомогою методу найменших квадратів, при цьому нелінійні функції приводяться до лінійного вигляду, а в нашому випадку значення параметрів прямої розраховуються за формулами:

$$
\begin{array}{r}
a_{0}=\frac{\sum_{i=1}^{n} Y_{i}}{n}, \\
a_{1}=\frac{\sum_{i=1}^{n} Y_{i} t_{i}}{\sum_{i=1}^{n} t_{i}^{2}}
\end{array}
$$

Прогноз розвитку явища здійснюється шляхом підстановки в отримане математичне рівняння тенденції відповідних порядкових номерів найближчих років t.

де $Y$ - емпіричні рівні ряду динаміки;

$n$ - число рівнів;

$t$ - час, тобто порядковий номер інтервалу або моменту часу.

\section{4. Приклад розрахунку}

Розрахунок параметрів значно спрощується, якщо за початок відліку часу прийняти центральний інтервал (або момент часу) аналізованого етапу. Тому що в нашому випадку кількість рівнів у ряду що вирівнюється парне, отже значення t установлюємо, В нашому випадку ланцюгові показники динаміки різко коливаються від року до року і 
постійно змінюють свій знак; розрахунок їх величини за раніше наведеними формулами дає невірну уяву про середню швидкість зміни рівня, відповідної загальної тенденції. Тому в даному випадку найбільш ефективним засобом виявлення основної тенденції розвитку є аналітичне вирівнювання. Для цього використовуємо формули $1.7-1.8$.

$$
a_{0}=\frac{\sum_{i=1}^{n} Y_{i}}{n}=\frac{9961+10803+10803+11523+10751}{5}=\frac{53841}{5}=10768,2 \text { (вик.), }
$$

В нашому випадку кількість рівнів у вирівнювальному ряді має непарне значення, тому порядкові номери інтервалу (Таблиця 2) будуть мати наступний вигляд:

Таблиця 2

\section{Порядкові номери інтервалу}

\begin{tabular}{|c|c|c|c|c|c|}
\hline Роки & $\mathbf{2 0 1 6}$ & $\mathbf{2 0 1 7}$ & $\mathbf{2 0 1 8}$ & $\mathbf{2 0 1 9}$ & $\mathbf{2 0 2 0}$ \\
\hline $\mathrm{T}$ & -2 & -1 & 0 & 1 & 2 \\
\hline
\end{tabular}

$$
a_{1}=\frac{\sum_{i=1}^{n} Y_{i} t_{i}}{\sum_{i=1}^{n} t_{i}^{2}}=\frac{9961 \times(-2)+10803 \times(-1)+10803 \times 0+11523 \times 1+10751 \times 2}{(-2)^{2}+(-1)^{2}+0^{2}+1^{2}+2^{2}}=230 \text { (вик.). }
$$

Використовуючи формулу 1.6 та отримані дані, рівняння вихідної прямої буде мати вигляд:

$$
\hat{Y}_{t}=a_{0}+a_{1} t=10768,2+230 t .
$$

Шляхом підстановки в це рівняння відповідних значень знайдемо вирівняні рівні $\hat{Y}_{t}$.

$$
\begin{gathered}
\hat{Y}_{2016}=10768,2+230 \times(-2)=10308,2 \text { (вик.); } \\
\hat{Y}_{2017}=10768,2+230 \times(-1)=10538,2 \text { (вик.); } \\
\hat{Y}_{2018}=10768,2+230 \times 0=10768,2 \text { (вик.); } \\
\hat{Y}_{2019}=10768,2+230 \times 1=10998,2 \text { (вик.); } \\
\hat{Y}_{2020}=10768,2+230 \times 2=11228,2 \text { (вик.). }
\end{gathered}
$$

Враховуючи, що крок інтервалу дорівнює 1, порядковий номер інтервалу, що прогнозується (2021 рік), буде дорівнювати 3. Тобто кількість викликів в наступному році буде дорівнювати: 


$$
\hat{Y}_{2021}=10768,2+230 \times 3=11458,2 \text { (вик.). }
$$

Зводимо показники динамічного ряду розподілу числа викликів і показники вирівняного ряду в таблицю 3.

Таблиця 3

Показники динамічного ряду розподілу числа викликів і показники вирівняного ряду

\begin{tabular}{|c|c|c|c|c|c|}
\hline Роки & $\begin{array}{c}\text { Кількість } \\
\text { викликів } \\
\boldsymbol{Y}_{\boldsymbol{i}}\end{array}$ & $\begin{array}{c}\text { Визначений } \\
\text { інтервал } \boldsymbol{t}\end{array}$ & $\boldsymbol{Y}_{\boldsymbol{i}} \boldsymbol{t}_{\boldsymbol{i}}$ & $\boldsymbol{t}_{\boldsymbol{i}}^{\mathbf{2}}$ & $\begin{array}{c}\text { Вирівняний } \\
\text { ряд } \boldsymbol{Y}_{\boldsymbol{t}}\end{array}$ \\
\hline 2016 & 9961 & -2 & -19922 & 4 & 10308,2 \\
\hline 2017 & 10803 & -1 & -10803 & 1 & 10538,2 \\
\hline 2018 & 10803 & 0 & 0 & 0 & 10768,2 \\
\hline 2019 & 11523 & 1 & 11523 & 1 & 10998,2 \\
\hline 2020 & 10751 & 2 & 21502 & 4 & 11228,2 \\
\hline$\sum$ & 53841 & 0 & 2300 & 10 & 53841 \\
\hline
\end{tabular}

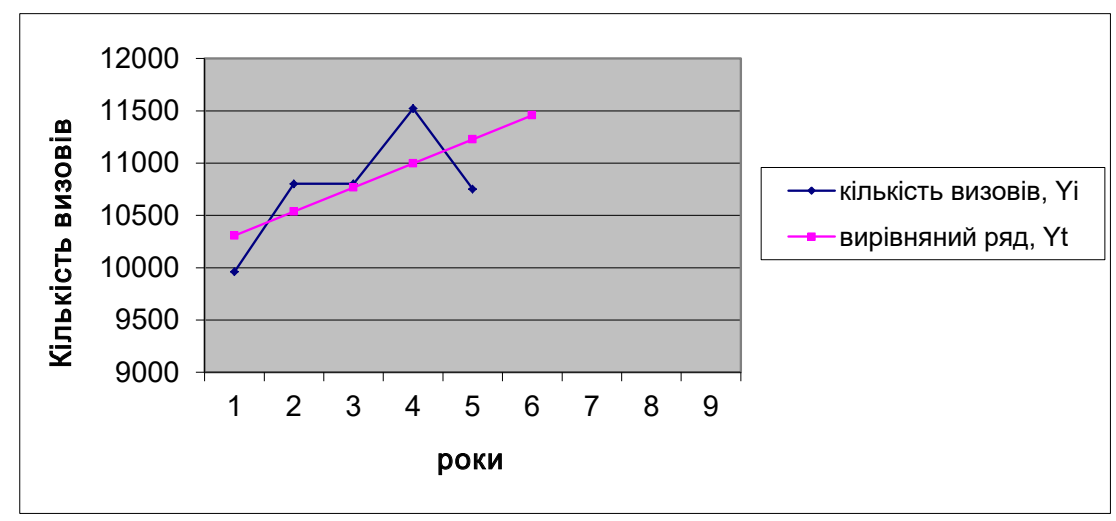

Рис. 3. Діаграма розподілу кількості раз гасіння пожеж ланками ГДЗС по рокам в Україні

\section{5. Обговорення результатів дослідження}

У дослідженні першим кроком для вирішення поставленої мети проводився аналіз статистичних даних кількості пожеж та надзвичайних ситу- 
ацій в місті (районі) по роках за 5 років; побудовано математичну модель динаміки числа пожеж та інших надзвичайних ситуацій. Визначено прогноз очікуваного числа їх виникнення та оцінено обсяг роботи ланками газодимозахисної служби на найближчий рік, а також визначено достатність сил і засобів. Найбільш ефективним способом виявлення основної тенденції розвитку числа надзвичайних ситуацій стало аналітичне вирівнювання за допомогою математичного виразу, що найбільш точно дав змогу описати характер емпіричного розподілу їх кількості за аналізований період і за допомогою якого нам вдалося спрогнозувати імовірну кількість пожеж, використавши математичний закон розподілу. Для визначення швидкості та інтенсивності розвитку кількості пожеж та інших надзвичайних ситуацій за певний час використано наступні показники: абсолютний приріст, темп зростання, темп приросту. Розрахунок цих показників грунтувався на порівнянні між собою рівнів ряду динаміки. Під рівнем ряду динаміки взято кожне окреме чисельне значення показника, який характеризує величину явища, його розмір і розташування в хронологічній послідовності. На основі описаних показників запропоновано методику розрахунку імовірної кількості пожеж у поточному році, які будуть ліквідовуватись ланками газодимозахисної служби. Відповідно до наших розрахунків і даних діаграми в 2021 році слід очікувати 11458 пожеж в Україні, які будуть ліквідовуватись ланками газодимозахисної служби.

\section{6. Висновки й перспективи подальших розвідок}

1. У науковому пошуку, проаналізувавши статистичні дані кількості пожеж та надзвичайних ситуацій в місті (районі) по роках, нами було побудовано математичну модель динаміки числа пожеж та інших надзвичайних ситуацій. Застосувавши Закон розподілу, було визначено прогноз очікуваного числа їх виникнення та оцінено обсяг роботи ланками газодимозахисної служби на найближчий рік, а також визначено достатність сил і засобів. У дослідженні найбільш ефективним способом виявлення основної тенденції розвитку числа надзвичайних ситуацій було аналітичне вирівнювання за допомогою математичного виразу, що посприяло найбільш точно описати характер емпіричного розподілу їх кількості за аналізований період і за допомогою якого вдалося виконати прогнозування. 3 цією метою поступово було підібрано необхідний математичний закон розподілу. Для визначення швидко- 
сті та інтенсивності розвитку кількості пожеж та інших надзвичайних ситуацій за певний час у статті використано наступні показники: абсолютний приріст, темп зростання, темп приросту. Розрахунок цих показників грунтувався на порівнянні між собою рівнів ряду динаміки. Під рівнем ряду динаміки взято кожне окреме чисельне значення показника, який характеризує величину явища, його розмір і розташування в хронологічній послідовності. На основі описаних показників запропоновано методику розрахунку імовірної кількості пожеж у поточному році, які будуть ліквідовуватись ланками газодимозахисної служби.

2. Наведено приклад розрахунку: описано основні його складові, які слід враховувати під час розрахунку. Досліджено процес зміни і розвитку виникнення і розповсюдження пожеж за допомогою побудови динамічних або часових рядів. Надано рекомендації щодо побудови математичної моделі динаміки числа пожеж та інших надзвичайних ситуацій, визначено прогноз очікуваного числа їх виникнення, оцінено обсяг роботи пожежно-рятувальних підрозділів на найближчий рік.

\section{Список літератури:}

1. Державна служба України 3 надзвичайних ситуацій. Національна доповідь про стан пожежної та техногенної безпеки в Україні. Київ, 2021. URL: http://dsns.gov.ua// (дата звернення: 05.03.2021).

2. Кодекс цивільного захисту України від 02 жовтня 2012 року № 5403-VI. Київ, 2021. URL: http://http://zakon4.rada.gov.ua/laws/show/5403-17// (дата звернення: 05.03.2021).

3. LFB : London Fire Brigade. Fire protection. URL: http://www.london-fire. gov.uk/ (дата звернення: 05.03.2021).

4. Наказ МНС України від 16.12.2011 № 1342 «Про затвердження Настанови з організації газодимозахисної служби в підрозділах Оперативнорятувальної служби цивільного захисту МНС України».

5. Наказ МВС України від 07.10.2014 № 1032 «Про затвердження Порядку організації внутрішньої, гарнізонної та караульної служб в органах управління і підрозділах Оперативно-рятувальної служби цивільного захисту Державної служби України з надзвичайних ситуацій».

6. R. Craig Schroll (2002) Industrial Fire Protection Handbook. 2nd Edition. P. 262.

7. DIN 14097-2 (2005) Firefighting and fire protection - Fire brigade training facilities. Part 2: Gas-fueled simulation facilities. P. 234.

8. Корольчук М.С., Крайнюк В.М. Соціально-психологічне забезпечення діяльності в звичайних та екстремальних умовах : Навчальний посібник для студентів вищих навчальних закладів. Київ : Ніка-Центр, 2006. 580 с. 
9. Основи психологічного забезпечення діяльності МНС : Підручник / За заг. ред. проф. О.В. Тімченка. Харків : Вид-во УЦЗУ, 2009. 217 с. $264 \mathrm{c}$.

10. Трофімов Ю.Л. Інженерна психологія : підручник. Київ : Либідь, 2002.

11. Фомич М.В. Розвиток професійно важливих якостей фахівців оперативно-рятувальної служби цивільного захисту : дис... кандидата психологічних наук : 19.00.09. Київ, 2012. 235 с.

\section{References:}

1. The State Emergency Service of Ukraine. Natsionalnaiia dopovid pro stan pozhezhnoii ta tekhnohennoii bezpeky v Ukraiini. Avaliable at: http://dsns.gov.ua/ (accessed 5 March 2021).

2. The Code of Civil Protection of Ukraine. Kodeks tsyvilnoho zakhystu Ukrainy]. Avaliable at: http://http://zakon4.rada.gov.ua/laws/show/5403-17/ (accessed 5 March 2021).

3. LFB: London Fire Brigade. Fire protection. Avaliable at: http://www.london-fire.gov.uk/ (accessed 5 March 2021).

4. The Order of State Emergency Service of Ukraine (2011) Pro zatverdzhennya Nastanovy $\mathrm{z}$ orhanizatsiyi hazodymozakhysnoyi sluzhby $\mathrm{v}$ pidrozdilakh Operatyvno-ryatuvalnoyi sluzhby tsyvilnoho zakhystu MNS Ukrayiny.

5. The Order of Ministry of Interior of Ukraine (2014) Pro zatverdzhennya Poryadku orhanizatsiyi vnutrishnoyi, harnizonnoyi ta karaulnoyi sluzhb v orhanakh upravlinnya i pidrozdilakh Operatyvno-ryatuvalnoyi sluzhby tsyvilnoho zakhystu Derzhavnoyi sluzhby Ukrayiny z nadzvychaynykh sytuatsiy.

6. R. Craig Schroll (2002) Industrial Fire Protection Handbook. 2nd Edition. P. 262.

7. DIN 14097-2 (2005) Firefighting and fire protection - Fire brigade training facilities. Part 2: Gas-fueled simulation facilities, $234 \mathrm{p}$.

8. Korolchuk M.S., Kraynyuk V.M. (2006) Sotsialno-psykholohichne zabezpechennya diyalnosti $v$ zvychaynykh ta ekstremalnykh umovakh: Navchalnyy posibnyk dlya studentiv vyshchykh navchalnykh zakladiv. Kyiv: Nika-Tsentr, 580 p.

9. Timchenko O.V. (2009) Osnovy psykholohichnoho zabezpechennya diyalnosti MNS. Pidruchnyk. Kharkiv: UCZU, 217 p.

10. Trofimov Yu.L. (2002). Inzhenerna psykholohiya. Pidruchnyk, 264.

11. Fomych M.V. (2012). Rozvytok profesiyno vazhlyvykh yakostey fakhivtsiv operatyvno-ryatuvalnoyi sluzhby tsyvilnoho zakhystu. Dysertatsiya kandydata psykholohichnykh nauk, 235 p. 